\title{
PRELIMINARY STUDIES ON SOME ASPECTS OF KIKUYU FOOD HABITS $\dagger$
}

\author{
JAN HOORWEG and RUDO NIEMEYER \\ Nutrition Intervention Research Project, Africa Studycentre, \\ Leiden, Netherlands
}

(Received May 22, 1979; in final form December 6, 1979)

\begin{abstract}
The preliminary studies presented in this paper were conducted prior to a comprehensive evaluation of child nutrition programmes among the Kikuyu in Kenya. They cover general aspects of Kikuyu food habits such as the foods presently in use, the classification of foods and food preferences for children. The emphasis is on the methods employed in these studies which can also be used elsewhere to obtain information vital to the evaluation and planning of child nutrition programmes.

A discussion on foods used by the Kikuyu in the rural areas is accompanied by a list of food names in the vernacular. Certain changes that have occurred over the last decennia are briefly touched upon. A quick method of studying food classification is described. There are no indications that the Kikuyu food classification differs substantially from the nutritional assignation generally used.

The remainder of the paper concentrates on the measurement of maternal food preferences. It is shown that the method of paired comparisons gives highly consistent and reliable results. Maternal preferences are also remarkably similar for different parts of Kikuyu country with a high preference for legumes and some starchy foods while certain cereals are held in conspicuously low regard.

KEY WORDS: food habits, Kenya; food planning, education; classification of foods; program evaluation; food preferences.
\end{abstract}

\section{INTRODUCTION}

A comprehensive evaluation of child nutrition programmes has been carried out in Central Province, Kenya, by the Nutrition Intervention $\mathrm{Re}$ search Project (NIRP). This comparative study of existing programmes in different ecological zones was broadly designed. It covered not only the nutritional status of the children but also included the knowledge, attitudes and dietary actices of mothers with respect to child nutrition. As part of this project, two nutrition surveys and other supporting studies were also carried out. The

project is described in detail in the original research proposal (NIRP, 1976) and the revised research plan (NIRP, 1978).

Child nutrition programmes not only teach mothers about foods and food groups, but often try to influence their preferences as well. Knowledge of the local food classification and of maternal food preferences is therefore a prerequisite for nutrition programmes, and in the kind of comprehensive evaluation attempted in this case, it is particu-

$\dagger$ The research reported here was financed by the Africa Studycentre, Leiden, Netherlands. larly important. This paper presents some studies conducted prior to the main project which deal with foods, food classification and food preferences of the Kikuyu, the tribe living in the area. After a general description of the Kikuyu household, kitchen and foods, four studies are presented, the first of which gives a complete list of foods presently used among this tribe and also the Kikuyu name of each food.

The Kikuyu use only a few generic food terms and have no words for food groups such as legumes, roots and tubers, cereals or spices. This might mean that they classify their foods differently, a possibility that requires investigation. There are various methods of studying the ways in which people classify objects. Most of these methods are very time consuming or require the actual presence of the objects themselves. A quicker method, employed in the second study, is to ask the respondents to name a food similar to that mentioned by the interviewer. In general, people tend to cite a food they consider to fall in the same food group.

A major concern at this stage of the project was how to measure food preferences. Food preferences can be studied not only by quantitative die- 
tary surveys but also by means of interviews such as attitude scales. Dietary surveys are important because they record actual behaviour. The results of the nutrition surveys conducted for this project will be published shortly. In a sense, however, preferences are only reflected indirectly, because behaviour is also decided by other factors such as costs, availability and suitability. Assessing preferences with the help of attitude scales not only provides additional data, but also data that can be collected quickly and easily. Previous research in Uganda has shown that the method of paired comparisons $\dagger$ is particularly suited for the study of food preferences of African mothers (Hoorweg and McDowell, 1979). When used for the first time, the method requires careful testing, because people may refuse to choose between certain types of foods. Moreover, attitude scales generally require extensive pre-testing. The third study concentrates on the methodological aspects of using paired comparisons with Kikuyu mothers.

Recent trends in nutrition education emphasize the importance of calories as well as proteins in the diet of young children. As far as evaluation is concerned, it would therefore be useful to be able to measure any changes in the preferences of the mothers for these two nutritional components. In the final study an attempt is made to do just that, to measure preferences for protein foods and for calorie foods independent of each other.

\section{GENERAL}

Since 1910, when the first comprehensive ethnography of the Kikuyu by the Routledges appeared in print, many changes have occurred in the Kikuyu household and kitchen, although certain things remain virtually unchanged. Traditionally, each married woman had her own hut with a thatched roof and built from wooden poles. The kitchen was in the centre of this round hut. Nowadays most houses are rectangular buildings with corrugated iron roofs. They are constructed of

$\dagger$ Respondents are asked to compare two foods and to select the one they prefer. Several foods are mentioned and usually all possible pairings or comparisons between these foods are presented to the mothers. For each comparison, the proportion of respondents choosing each alternative can be computed. When foods are presented in more than one comparison, as is usually the case, the average proportion of choices for each food can also be computed. The data can further be analysed with the help of more advanced scaling models (Kendall, 1970; Romney, Shepard and Nerlove, 1972, Torgerson, 1958). mud on a wooden frame and serve as shelter for the whole family, not for only one woman with her young children. In small houses the kitchen is often combined with a living room, but in the larger houses it is usually a room by itself or may even be a separate building.

Most Kikuyu housewives in the rural areas still prepare meals over a wood fire as their grandmothers used to do, wedging pots and pans between a few big stones. In the kitchen one usually finds only the bare necessities: a container to collect water, a few gourds, some stools and perhaps a small cupboard. Cheap crockery and cutlery have replaced the traditional implements; instead of earthen pots most housewives now use sufuria's, the drab, gray, metal containers without lids that are found all over Africa. The earthen pots now reserved mainly for one dish, maize a beans. $\ddagger$

Usually a family eats three meals a day: a meagre breakfast, a second meal early in the afternoon between one and three and the last meal at night between seven and nine. After these meals people often drink tea prepared with plenty of milk and sugar, or else tea may be taken during the morning or during the afternoon.

The staple food of the Kikuyu is maize, which can be roasted or boiled on the cob when fresh, although usually the grains are removed from the cob. The favourite staple dish is whole maize with kidney beans boiled together (githeri). This is usually prepared every day or two. Individual meals usually consist of a portion of this basic dish to which vegetables, green bananas, potatoes, or seasonings may be added to give variety to the two main meals of the day. Other kinds of beans or peas can be added or may replace the kidney beans. Occasionally some meat may also be add In some areas the githeri meals are often mashed, in other areas hardly ever. Githeri is highly favoured as the basic dish, but stiff maize flour * porridge (ngima) serves as an alternative, either when whole maize is not available or as a quick dish that requires less time to prepare. Another alternative is gitoero, a stew of starchy roots or tubers. Some roots are also eaten alone, boiled with a little salt. On rare occasions a rice dish may be served.

Although the Kikuyu used to plant a variety of

$\ddagger$ Where reference is made to beans or potatoes without further specification, kidney beans (Phaseolus vulgaris) or Irish potatoes (Solanum tuberosum) are meant. 
grains, they now grow mostly maize, introduced early in the last century (Bertin et al., 1971). The areas presently under cultivation with millet, sorghum and wheat are insignificant; these grains usually have to be purchased. Maize and rice are the only cereals that serve as staple foods, while millet and sorghum flour are mainly given to children as a light porridge. Wheat flour is used for an occasional pancake.

Several roots, tubers and starchy fruits are grown. Those most frequently consumed are green (cooking) bananas and Irish potatoes, which are added to githeri or eaten as a stew. Sweet potato is usually eaten by itself. Irish potatoes, which were introduced at the turn of the century, have become very popular. Cassava, yam, and taro, which is vally called arrow root, are less frequently eaten.

The kidney bean (Phaseolus vulgaris) is the most common legume, together with the ordinary pea (Pisum sativum) and the cowpea (Vigna spp.) The Bonavist bean (Lablab niger) and the pigeon pea (Cajanus cajan) are regarded as delicacies and served in ceremonial dishes at marriage and child birth occasions. The lima bean (Phaseolus lunatus) which is locally and erroneously called soya bean, the mung bean (Phaseolus aureus) and the groundnut (Arachis hypogaea) are available but less frequently used.

The vegetables most often prepared are cabbage, cowpea leaves, pumpkin leaves and kale. This last green, although introduced only recently, has become very popular. It has probably replaced many other plant leaves, particularly many of the wild leaves whose consumption seems to have greatly declined. Onions, peppers, tomatoes and carrots are used frequently as seasonings.

Fruits are usually eaten by children between . eals; and sweet banana, mango and passion fruit, in particular, are very popular. Usually fruits are not difficult to obtain when in season, but cape gooseberries (Physalis peruviana), pears, plums and tangerines are only grown in certain areas.

Spices, largely absent from Kikuyu cooking, are limited to salt and, sometimes, curry powder. Ginger powder is sometimes added to tea, while sodium bicarbonate may occasionally be used in cooking vegetables not so much to add taste as to make the leaves more tender.

The traditional Kikuyu diet is basically vegetarian because meat was "the luxury of the few, and only partaken of in small quantities on occasions of sacrifices or festivals" (Routledge and Routledge, 1910, p. 49). Another observer, how- ever, noted that in the old days the men of the tribe consumed considerable quantities of meat, although erratically. Women and children, however, ate much less meat than men because they were often not allowed to be present at such ceremonial occasions and, if allowed to be present, they were usually given the less favoured parts of the animal (Leaky, 1977, p. 255).

The frequency of traditional ceremonies has declined since then, and meat consumption is still very limited and perhaps even more restricted to adult men who are able to buy roasted meat in bars and at other selling points. The meats that are consumed are mostly beef, goat, mutton and chicken. Fish, pork and rabbit are seldom eaten. The consumption of milk and eggs seems to have increased considerably over the past decade, and milk in particular has become an important foods not only for children but for adults as well.

\section{MATERIALS AND METHOD}

\section{Study I}

The foods on sale at several local markets were recorded. This list was extended in discussions with several Kikuyu assistants, themselves mothers of small children. The existing literature was screened for any omissions (Anderson, 1937; Bohdal Gibbs and Simmons; Middleton and Kershaw, 1965; Orr and Gilks, 1931; Procter, 1926; Routledge and Routledge, 1910). Certain of these foods are only rarely used, and some are probably never consumed in some households but they were included to be complete. Truly exceptional foods, foods that are known but that are virtually never eaten, for example, antelope meat, grasshoppers or stinging nettle, are not included. No attempt was made to assess how the foods used by the Kikuyu in town differ from this list which is valid for the rural areas only. The Kikuyu name for each food was recorded by our assistants. The list of regional food names by Blankhart (1974) and the Kikuyu dictionaries by Benson (1964) and Benson and Barlow (1975) were used for confirmation. These translations were later corrected with the help of a Kikuyu language teacher.

The final list presented in the form of a small dictionary (NIRP, 1977) has proved quite complete in the further course of the project. It contains more than 120 entries, 40 of which refer to general concepts, drinks, meals with specific names and certain cereal products. The remaining entries form the basic foods presently used by the rural Kikuyu and are listed in Table 1 according to the divisions used in the food tables by Platt (1962), with the corresponding scientific and Kikuyu names.

Study 2

Food names were read out, one by one, to Kikuyu mothers of young children. They were instructed to name another food similar to the one mentioned by the interviewer. The 64 most common foods marked with an ${ }^{2}$ in Table I were selected for 
TABLE I

List of foods consumed by Kikuyu in Kenya , *

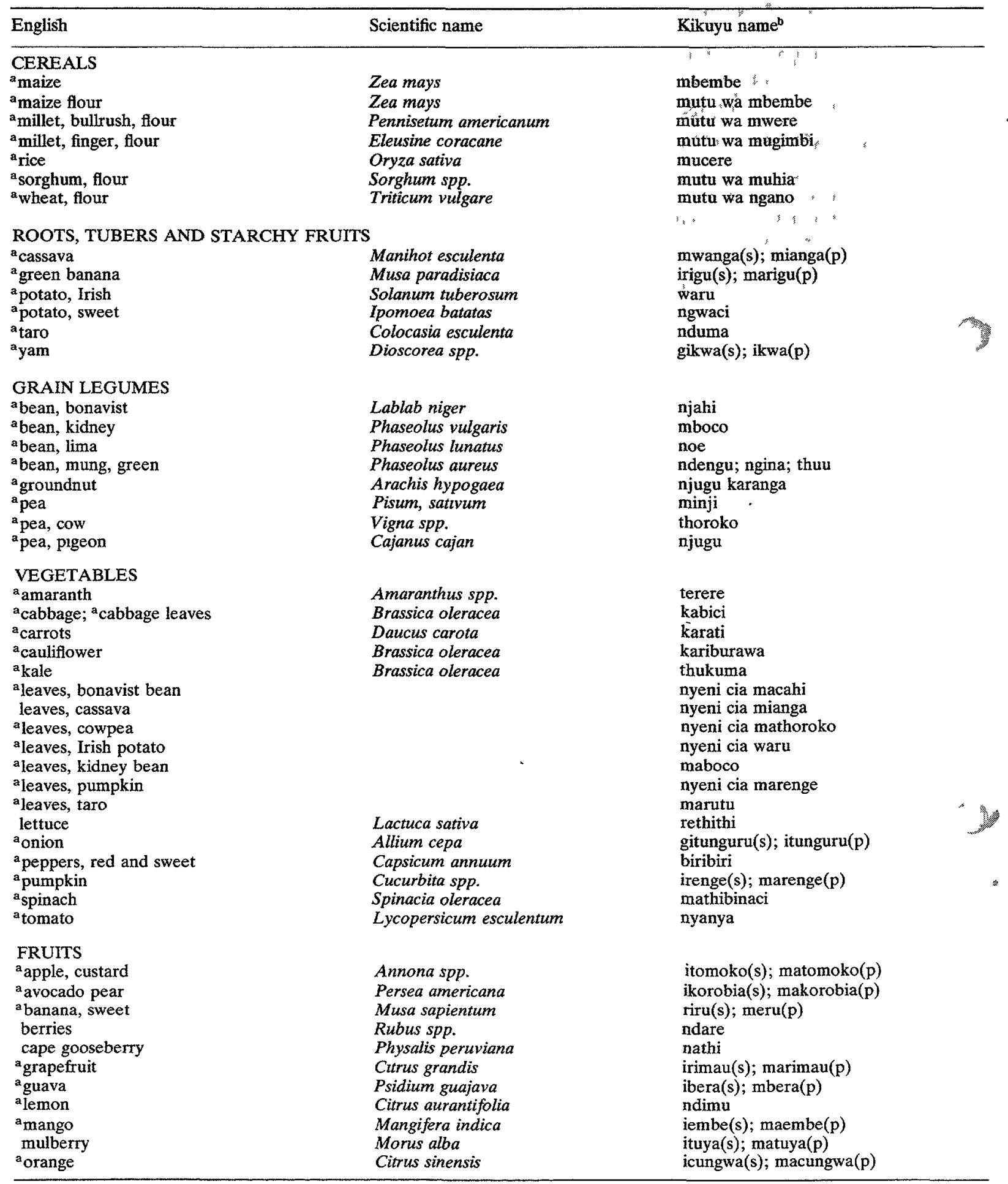


TABLE I (continued)

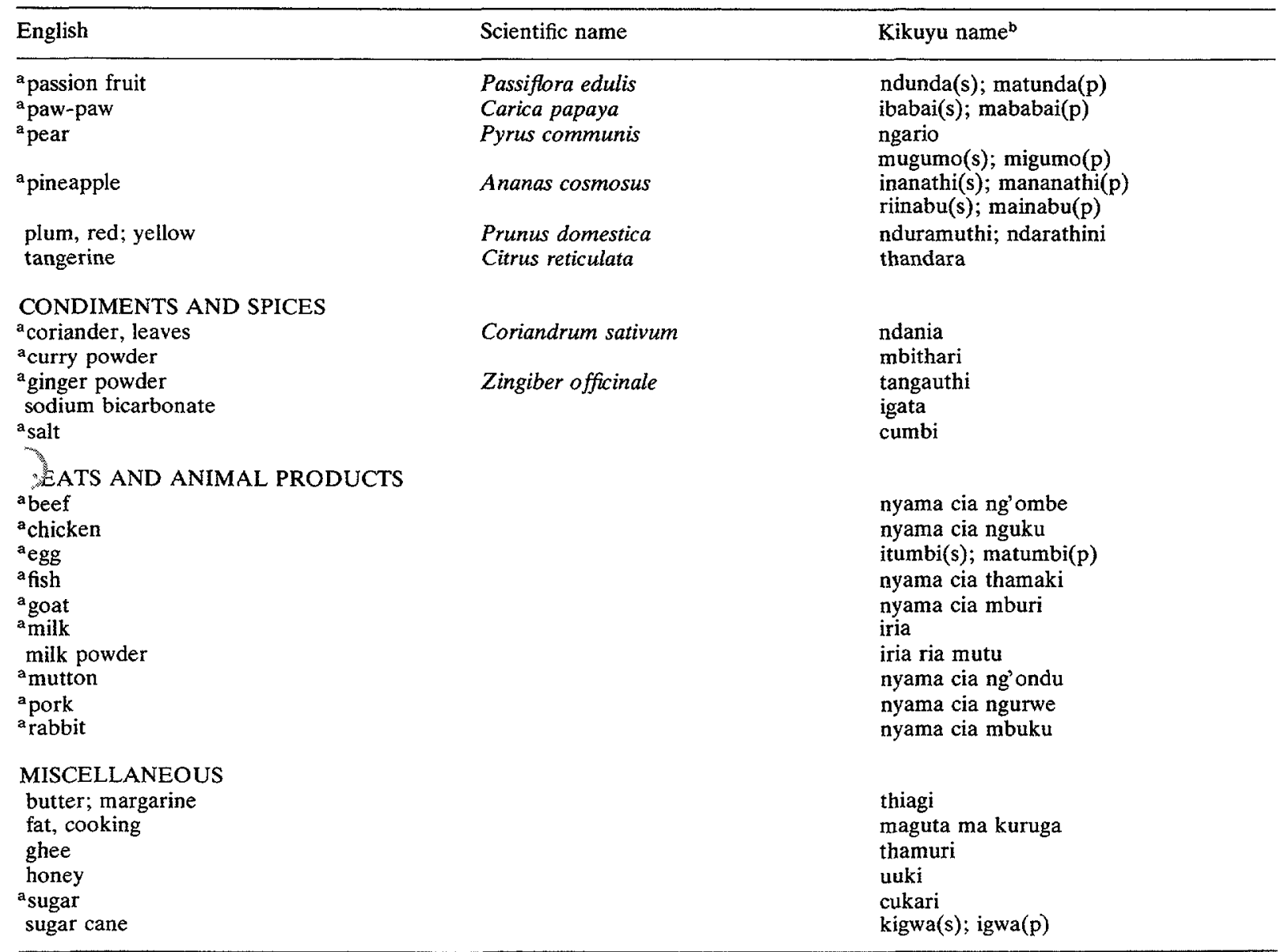

${ }^{a}$ Foods selected for inclusion in study 2.

${ }^{\mathrm{b}} \mathrm{Food}$ names in Kikuyu are listed in singular(s) and plural(p). Names that are known in only one form are given without further indication.

On study. They were divided into six lists of ten or 11 foods. One of these smaller lists was presented to each respondent. Respondents for each of the six lists were 30 mothers of young children attending MCH clinics, 20 in Kiambu town and ten in Kambaa village, a total of 180 respondents.

Platt's (1962) groupings of foods served as a starting point for the analysis. For each food the number of times foods from the same food group and the number of times foods from other groups were mentioned, were counted. If most responses and at least one third of the replies consisted of foods within the same group a food was retained in this-its original group. If these two conditions were not met it was removed from the group and only reassigned to another group when one third or more of the responses fell in that group. After each permutation all previous calculations were reviewed until, finally, stable groups remained.

One food, pumpkin, was reallocated and had to be classified as a root and tuber, instead of a fruit. Onions, peppers, carrots and tomatoes had to be removed from the group of vegetables but did not belong to any other group either. The four spices and sugar failed to constitute a group and also did not belong to other groups.

\section{Study 3}

Kikuyu mothers of small children were presented with a number of comparisons between two foods and asked, "Which food would you prefer to give to a two-year-old child?"

The study was conducted in three stages. In the first stage the mothers were given 12 comparisons within the six main food groups: cereals, roots and tubers, legumes, vegetables, fruits, meats and animal products. The foods were those that had most often been mentioned in the previous classification study together with some foods that were considered particularly interesting (interviews $1 \mathrm{~A}$ and $1 \mathrm{~B}$ ).

Next, foods from different but still related food groups were compared with each other (interviews $2 \mathrm{~A}$ and $2 \mathrm{~B}$ ). Interview $2 \mathrm{~A}$ combined the staple foods and consisted of the two most 
popular roots and tubers, the two most popular grains and also the two most popular flours (most popular according to interviews $1 \mathrm{~A}$ and $1 \mathrm{~B}$ ). Interview $2 \mathrm{~B}$ combined the two most popular vegetables, the two most popular legumes, eggs and meat. Each interview consisted of 15 comparisons.

In the third stage mothers chose between all kinds of foods (interviews $3 A$ and $3 B$ ). The interviews for this study contained one food from each of the six major food groups. The most popular foods were combined in $3 \mathrm{~A}$, the second most popular foods in $3 \mathrm{~B}$. Each interview schedule also included rice and consisted of 21 comparisons.

Four hundred and eighty Kikuyu mothers attending MCH clinics were interviewed. For each of the six interviews there were 80 mothers. Interviews $1 \mathrm{~A}$ and $1 \mathrm{~B}$ were conducted with 40 women in Kiambu and 40 women in Kambaa respectively. Interviews $2 \mathrm{~A}, 2 \mathrm{~B}, 3 \mathrm{~A}$ and $3 \mathrm{~B}$ were conducted with 20 women in Kiambu, 40 women in Kambaa and 20 women in Kigumo respectively. Kiambu is a district capital situated in the middle of the coffee zone. Kambaa is a small village in a different ecological zone at a higher altitude, $50 \mathrm{~km}$ from Nairobi. Both research locations are in Kiambu district. The third location, Kigumo, is a village in the centre of Muranga district, $35 \mathrm{~km}$ from the district capital at the altitude where the coffee and tea zones meet.

Study 4

The procedure was the same as in Study 3, but comparisons between foods were limited to choices between the following groups:

Group A: High calories-high proteins; legumes and animal products: beans, peas, eggs, meat.

Group B: High calories-low proteins; cereals: millet flour, rice, maize flour.

Group C: Low calories-low proteins: roots and tubers, vegetables, fruits: green banana, Irish potato, cabbage, orange.
Each group consists either of three or four foods; there are 12 comparisons possible between groups $\mathrm{A}$ and $\mathrm{B}, 12$ between groups $B$ and $C$ and 16 between groups $A$ and $C$. Since an interview of 40 comparisons was deemed too long to be given to individual respondents, it was split in two halfs of 20 comparisons, each consisting of six $\mathrm{A}-\mathrm{B}$, six B-C and eight A-C comparisons.

Each list of 20 comparisons was presented to 120 Kikuyu mothers with young children at the same clinics as above: 40 mothers in Kiambu, 40 in Kambaa and 40 in Kigumo.

\section{RESULTS AND DISCUSSION}

\section{Reliability}

The quality of data from classification and preference studies depends to a large extent on the kin of task set out for the respondents. Particular ${ }_{s, 2}$ among people who are not familiar with interview situations, it is important that they see it as natural.

The task in the second study, the classification of foods, posed few problems. In general the respondents had no difficulty understanding what was expected from them and they answered quickly and decisively. In less than ten percent of the cases were they unable to recall another food. The percentage "no response" for each food group is presented in Table II.

The quality of the data in the third study, on food preferences, requires more detailed attention. Mothers had no difficulty in choosing between foods, irrespective of whether these foods

TABLE II

Number of times a food group was mentioned in responses made by Kikuyu women to different foods (average percentage per group) ${ }^{2}$

\begin{tabular}{|c|c|c|c|c|c|c|c|c|c|c|}
\hline & & \multicolumn{9}{|c|}{ RESPONSES } \\
\hline & & 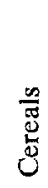 & 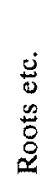 & 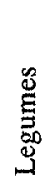 & 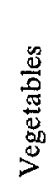 & 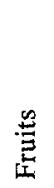 & 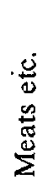 & 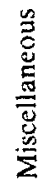 & 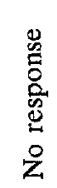 & \\
\hline \multirow{6}{*}{ 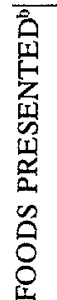 } & $\begin{array}{l}\text { Cereals } \\
\text { Roots, tubers and }\end{array}$ & 76 & 8 & 6 & 1 & - & 2 & 1 & 6 & $100 \%$ \\
\hline & starchy fruits & 6 & 71 & 3 & 3 & 6 & 1 & 3 & 7 & $100 \%$ \\
\hline & Legumes & 3 & 2 & 78 & 4 & - & 3 & 1 & 9 & $100 \%$ \\
\hline & Vegetables & 3 & 5 & 4 & 76 & - & 4 & 1 & 7 & $100 \%$ \\
\hline & Fruits & - & 5 & - & 1 & 74 & 1 & 6 & 13 & $100 \%$ \\
\hline & $\begin{array}{l}\text { Meats and animal } \\
\text { products }\end{array}$ & 1 & 2 & 3 & 3 & - & 81 & 2 & 8 & $100 \%$ \\
\hline
\end{tabular}

a Study 2 .

${ }^{\mathrm{b}} \mathrm{A}$ list of the individual foods that were presented is included in Table I. 
TABLE III

Estimates of reliability for interviews of Kikuyu women ${ }^{a}$

\begin{tabular}{ccc}
\hline $\begin{array}{c}\text { Interview } \\
\text { schedule }\end{array}$ & $\mathrm{r}$ & $\mathrm{r}$, corrected $^{\mathrm{b}}$ \\
\hline 1A & 0.96 & 0.98 \\
1B & 0.96 & 0.98 \\
2A & 0.94 & 0.97 \\
2B & 0.87 & 0.93 \\
3A & 0.92 & 0.96 \\
3B & 0.95 & 0.97 \\
\hline
\end{tabular}

aStudy 3 .

${ }^{\mathrm{b}}$ Each half consists of 40 persons. Since the proportions presented below for the different interview schedules are all based on samples of 80 people, corrected estimates according to Spearman-Brown are also presented.

are drawn from the same, or from different food groups. Their answers show consistent patterns and the reliability estimates for the different interview schedules that follow below confirm that they do not answer haphazardly.

For each of the six interview schedules of Study $3(1 \mathrm{~A}, 1 \mathrm{~B} ; 2 \mathrm{~A}, 2 \mathrm{~B} ; 3 \mathrm{~A}, 3 \mathrm{~B})$, the group of respondents was randomly divided in half. In this way, two proportions were obtained for each comparison in each interview schedule. The correlation between these two proportions indicates the similarity between the results in the two "half" groups and was computed for each interview schedule separately. This is a measure of reliability. $\dagger$ As shown in Table III these correlations are not only high, but, relatively, constant.

If respondents had not been able to compare foods from different food groups or unable to choose meaningfully between them, the reliability of their choices would have declined, that is, the ability of interview schedules $2 \mathrm{~A}$ and $2 \mathrm{~B}$ would werve been lower than that of $1 \mathrm{~A}$ and $1 \mathrm{~B}$. The reliability of interview schedules $3 A$ and $3 B$ would , have been lowest. Since no such decline is found, the choices made between foods from different food groups are as meaningful as the choices between foods from the same group.

This is confirmed by another indicator of the consistency of choices, the incidence of circular

$\dagger$ These reliability coefficients differ from ordinary split-half coefficients. Usually the group of items is divided in half but in this case the group of respondents is divided. As a consequence the present coefficients do not estumate the reliability of individual preferences but indicate the precision by which the obtained proportions estimate the true proportions in the population. triads. $\$$ Again, if comparing foods from different food groups is not meaningful, one would expect respondents to become less consistent in their choices and the number of circular triads would increase from stage 1 to stage 3. Table IV shows the average number of circular triads and the total number of triads for each interview schedule, after correction for unpopular foods which were seldom chosen. (A detailed discussion can be found in Hoorweg and Niemeyer, 1978b). There is no noticeable increase in circular triads with the possible exception of $3 \mathrm{~A}$. This last interview contains the foods that were found to be most popular during the first stage of the study. This may suggest that respondents find it slightly more difficult to choose consistently between very popular foods.

TABLE IV

Incidence of circular triads as a test of reliability of unterviews of Kikuyu mothersa

\begin{tabular}{cccc}
\hline Interview & $\begin{array}{c}\text { Average } \\
\text { number per } \\
\text { person } \\
\text { schedule }\end{array}$ & $\begin{array}{c}\text { Number of } \\
\text { triads } \\
\text { presented } \\
(\mathrm{B})\end{array}$ & $\begin{array}{c}\text { Average per- } \\
\text { centage per } \\
\text { person } \\
(\mathrm{A} / \mathrm{B} \times 100 \%)\end{array}$ \\
\hline 1A & 0.3 & 5 & 6 \\
1B & 0.8 & 6 & 13 \\
2A & 1.3 & 10 & 13 \\
2B & 2.6 & 20 & 13 \\
3A & 3.5 & 20 & 18 \\
3B & 3.8 & 35 & 11 \\
\hline
\end{tabular}

aStudy 3.

Both indicators, the split-half coefficients and the incidence of circular triads, point to an acceptable reliability for this method of measuring food preferences among Kikuyu mothers.

Correlations between preferences in the different locations in Central Province where interviews were conducted, were computed in the same way as for the split-half results. Although minor cultural differences exist between the Kikuyu living in Kiambu and Muranga districts, the food preferences of the women in Kambaa and Kigumo, two villages in these districts, are much the same (Table V). Preferences were also quite similar in Kiambu and Kambaa, locations which differ in

$\neq$ A circular triad occurs when a respondent prefers $X$ over $Y$ and $Y$ over $Z$ but instead of choosing $X$ over $Z$, as would be expected, she chooses $Z$. When more than three stimuli are studied more complicated inconsistencies may occur involving more than three foods but for purposes of analysis these are usually broken down into triads. 
TABIEN V

Correlations between preferences of Kikuy u womenliving in three different areas of $\mathrm{Kenya}^{\mathrm{a}} \mathrm{W}, \mathrm{s}$

\begin{tabular}{|c|c|}
\hline $\begin{array}{l}\text { Interview } \mathrm{Kambaa} \text { Kambu } \\
\text { schedule } \mathrm{T}\end{array}$ & $\begin{array}{l}\text { Kambaariguno } \\
\text { T }\end{array}$ \\
\hline 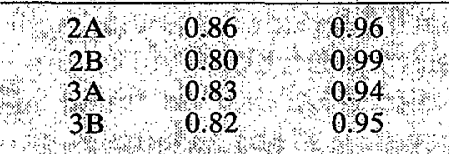 & $\begin{array}{l}094, \\
087 \\
085\end{array}$ \\
\hline
\end{tabular}

study 3 .

bThe usual correction for attenuation was applied utilizing reliabilities calculated for the Kanbaa, Kiambu and Kigumo data separately (Table III.)

terms of ecological zones and the presence of urban health facilities. It may be concluded that regional differences in food preferences, if any, within Kikuyu territory are very small and this in turn suggests that the results of the present study will be fairly representative of the food preferences of Kikuyu mothers in general.

\section{Food Classification. Among the Kikuyu}

The Kikuyu word for food in general is irio. $\dagger$ Fruits are known as matunda, green leaves as nyeni. Mboga means cabbage but may occasionally indicate vegetables in general, including green leaves. Meat is called nyama; different kinds of meat are identified by reference to the particular animal. Similarly, mutu is flour and individual flours are named after the grains. Finally, hindi stands for all kinds of small seeds and grains. As mentioned before there are no words in Kikuyu for food groups such as legumes, roots and tubers, cereals. or spices which might suggest that the Kikuyu classify their foods differently.

The results of the second study (Table II) show that this is not the case. More than 70 percent of the foods mentioned by the respondents are from the same nutritional groups as the foods presented by the interviewer. This includes groups that have no Kikuyu names. Evidently, Kikuyu women distinguish at least the six major food groups: cereals; roots, tubers, and starchy fruits; legumes; vegetables; fruits; meats and animal products. They seem to make no further divisions within these groups. There is also no indication that some of

\footnotetext{
$\dagger$ It is confusing that in the Nairobi-Kiambu area the word irio is also used for the mash of githeri with potatoes, bananas or greens which is particularly popular in this area.
}

the se groups are less cleary identifed than others or that some groups are cleser to each other than others. Mhere is some evidence that Kikuyu women also disting uish, although far less clearly, a group of seasomings which combine a few spices with carrots, onions, peppers and tomatoes (Hoorweg and Niemeyer, 1978.

A few pecularities in the grouping of certan foods are of potential interest Wh tegard to nutrtron education. For each ind widlual food the percentage of responses an the same food group is never less than 33.3 percent (otherwise the food would lave (been renoved from that group) and averages 76 percent Her Whole marre, rice and green bananas, 10 wever these percentages were only 37,53 and 38 respectively, indicating that these foods belong only marginaly to their resp tive groups. In many cases whole maze and rice were classified as roots or tubers 1 in adation 27 percent of the respondents were not able to name any food they regarded as similar to green bananas and 21 percent associated this last food with fruits. In nutrition education programmes among the Kikuyu it might be useful to emphasize the relationship of maize and rice to other cereals as very nutritious foods. In addition, the relationship between green bananas and other starchy foods should be stressed since the caloric and protein content of these foods is uniformly low. The relationship of milk and eggs to meats was perceived by only 42 percent and 63 percent of the respondents, respectively. It seems advisable to discuss the nutritional qualities of milk and eggs individually and not in connection with meats, particularly because meats are seldom eaten.

The general conclusion of this study, however, is that nutrition education and nutrition researr among the Kikuyu can safely be based on th common nutritional classification of foods.

\section{Preferences of Kikuyu Mothers for Children's Foods}

The general pattern of child feeding that has been described for many other sedentary African tribes is also found among the Kikuyu. Children are breastfed on demand, and at 4-5 months of age the first solid supplementary foods are introduced. These may be millet porridge or a mash of bananas and potatoes, although cow's milk may be given at an earlier age. During the following months additional foods are introduced. While some, such as cooked beans are introduced early, others are 
TABLE VI

Average proportion of choices made by Kikuyu women for different foods (interview schedules $1 \mathrm{~A}$ and $1 \mathrm{~B})^{\mathrm{a}}$

\begin{tabular}{|c|c|c|c|}
\hline \multirow{2}{*}{\multicolumn{2}{|c|}{$\begin{array}{c}(1 \mathrm{~A}) \\
\text { Meats and animal products }\end{array}$}} & \multicolumn{2}{|l|}{ (1B) } \\
\hline & & getables & \\
\hline eggs & 0.90 & kale & 0.84 \\
\hline chicken & 0.55 & cabbage & 0.51 \\
\hline goat meat & 0.30 & cowpea leaves & 0.37 \\
\hline beef & 0.26 & pumpkin leaves & 0.28 \\
\hline \multirow{4}{*}{$\begin{array}{l}\text { Cereals } \\
\text { millet flour } \\
\text { maize flour } \\
\text { wheat flour }\end{array}$} & \multicolumn{2}{|c|}{ Legumes } & \\
\hline & 0.91 & beans & 0.81 \\
\hline & 0.46 & peas & 0.45 \\
\hline & 0.14 & pigeon peas & 0.25 \\
\hline \multirow{5}{*}{$\begin{array}{c}\text { Fruits } \\
\text { or }\end{array}$} & \multicolumn{2}{|c|}{ Roots and tubers } & \\
\hline & 0.73 & green banana & 0.69 \\
\hline & 0.73 & Irish potato & 0.55 \\
\hline & 0.04 & sweet potato & 0.27 \\
\hline & & $\mathrm{N}=80$ & \\
\hline
\end{tabular}

${ }^{\text {a Study } 3 .}$

introduced late and include whole maize which is only given to children when they reach the age of two or three years. Most children are weaned between six and 18 months, usually around the age of one year (CBS, 1977). By the age of three most children not only eat with the adults but also eat the same meals as the adults although they may still be given some extras such as millet porridge and perhaps eggs, depending upon the mother. It is between the ages of one and three years that children run great nutritional risks, that mistakes are easily made in children's diets and that maternal food preferences are very important.

Table VI shows the average proportion of choices of Kikuyu mothers for different foods, computed from the comparisons of these foods

* th several others in the same group. $\dagger$ For example, the proportion of respondents preferring oranges over mango and sweet banana is 0.95 and 0.51 respectively. The average proportion of choices for oranges is therefore 0.73 .

At this point it is important to emphasize that we are not dealing with people's behaviour but with their verbally expressed preferences and that these are not identical for many reasons. Nevertheless, the results are not surprising to those familiar with the diet of the young Kikuyu child. The high preference for millet flour among the cereals is to be expected because it is mainly used to prepare

$\div$ Detailed results for individual comparisons have been presented elsewhere (Hoorweg and Niemeyer, 1978b). ucuru, children's porridge. Among the animal products, preferences seem strongly related to tenderness; beef, which is generally eaten rather tough, is the least preferred for children. Green bananas and Irish potatoes are more popular than sweet potato. Beans are the most popular legume; kale and cabbage are liked most among the vegetables. Somewhat surprising is the high preference for oranges, a fruit which is less common than sweet banana.

When respondents were asked to choose between various staple foods, green bananas and millet flour proved most popular followed by maize flour and Irish potatoes (Table VII). Rice and maize are the least popular staple foods for children. Maize, as previously noted, is usually not given as a whole grain to children younger than three years. Another group of respondents chose between animal products, vegetables and legumes. Beans are the most preferred food, followed by eggs and kale. Meat, peas and cabbage are lower on the list.

Two interview schedules consisted of comparisons between foods from all the different food groups. The first includes the most popular foods from each food group and rice. Beans and eggs are highly preferred for young children. Kale next, while millet flour, a very nutritious food, shares its place with green bananas and oranges. Rice is least preferred (Table VIII). Interview schedule 3B combines the second most popular foods (with the exception of chicken, which was replaced by meat) with rice. Meat and peas are highly preferred, but so are sweet banana and cabbage. Maize flour, Irish potatoes and rice are lower on the list.

In general, the staple foods, green bananas, millet flour, rice, maize flour and Irish potatoes are less preferred than other foods. With respect to

TABLE VII

Average proportion of choices made by Kikuyu women for different foods (interview schedules $2 \mathrm{~A}$ and $2 \mathrm{~B})^{\mathrm{a}}$

\begin{tabular}{llll}
\hline \multicolumn{1}{c}{$(2 \mathrm{~A})$} & \multicolumn{2}{c}{$\begin{array}{c}\text { 2B) } \\
\text { Cereals, roots and tubers }\end{array}$} & \multicolumn{2}{c}{$\begin{array}{c}\text { Vegetables, legumes, meats } \\
\text { and animal products }\end{array}$} \\
green banana & $0.74 \quad$ beans & 0.75 \\
millet flour & 0.69 & eggs & 0.60 \\
maize flour & 0.51 & kale & 0.56 \\
Irish potato & 0.45 & meat & 0.40 \\
rice & 0.43 & peas & 0.39 \\
maize (whole grain) & 0.19 & cabbage & 0.31 \\
$\mathrm{~N}=80$ & & $\mathrm{~N}=80$ & \\
\hline
\end{tabular}

a Study 3. 
TABLE VIII

Average proportion of choices made by Kikuyu women for different foods (interview schedules $3 \mathrm{~A}$ and $3 \mathrm{~B}$ ) ${ }^{\mathrm{a}}$

\begin{tabular}{llll}
\hline (3A) & & $(3 \mathrm{~B})$ & \\
beans & 0.73 & meat & 0.73 \\
eggs & 0.70 & sweet banana & 0.67 \\
kale & 0.57 & cabbage & 0.66 \\
green banana & 0.47 & peas & 0.63 \\
millet flour & 0.46 & maize flour & 0.29 \\
arange & 0.43 & Irish potato & 0.27 \\
rice & 0.14 & rice & 0.25 \\
$\mathrm{~N}=80$ & & $\mathrm{~N}=80$ & \\
\hline
\end{tabular}

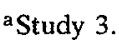

nutritional qualities, foods which are high in proteins as well as in calories; beans, eggs, meat, peas are often chosen. Foods that are high in calories but lower in protein content, millet flour, maize flour and rice, do not follow but are at the bottom of the list. Nutritionally poorer foods, low both in proteins and calories include sweet banana, cabbage, kale and green bananas and they are favoured more. Evidently, the preferences of Kikuyu mothers only partly correspond with the nutritional qualities of the foods.

Nutrition intervention in Africa and elsewhere has generally emphasized the importance of proteins in the diet of young children. Gopalan (1968) and McLaren (1974) were among the first to argue that the child's need for calories has not received enough attention. Nutrition education should also

TABLE IX

The percentage of respondents preferring different foods, presented for individual comparisons

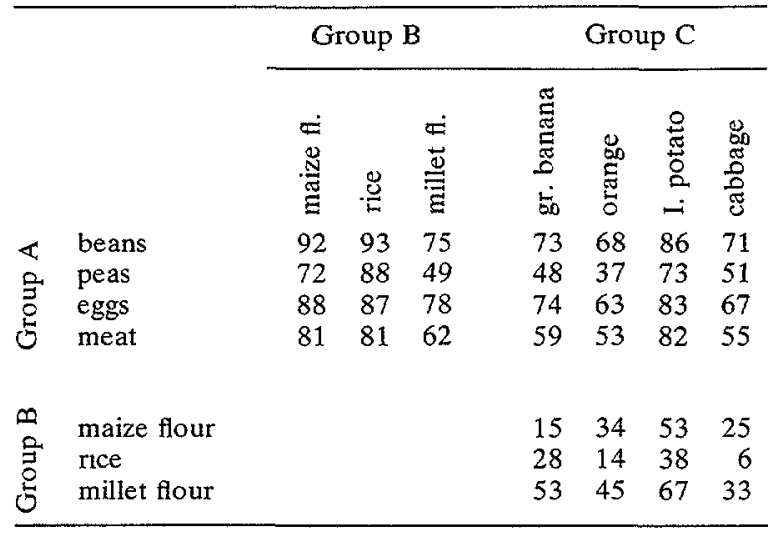

${ }^{a}$ Study 4 ; Each cell contains the percentage of respondents preferring the food on the left hand side of the table. For example, 92 percent of the respondents prefers beans over maze flour. $\mathrm{N}=120$. stress the importance of calories in the young child's diet. Consequently when studying the effects of nutrition education, it is important to be able to measure the mother's preferences for protein foods and for calorie foods separately. The difficulty here is that the common high protein foods, such as beans, are also high in calories, and a choice of such a food is a choice for both nutritional components. What is needed is a method that can separate a preference for high protein foods from that for high calorie foods and vice versa. Study 4 employed a scale limited to comparisons between foods designated Group A having a high calorie and a high protein content; and foods in Group B having a high calorie content and a much lower protein content; and foods in Group $\mathrm{C}$ which are low, both in proteins and calori Table IX shows the respective preferences for each comparison, presented in a condensed matrix.

$A-B$ comparisons Foods in groups $\mathrm{A}$ and $\mathrm{B}$ are high in calories but differ in protein content. The degree to which a respondent prefers group A foods over group B foods indicates the degree to which she prefers high-protein foods over low protein foods for the young child. An average of 79 percent of the respondents prefer group A foods to those of group B. Only 21 percent prefer the low protein foods. Thus, we find a strong preference among Kikuyu mothers for foods with a high protein content.

$B-C$ comparisons Although the foods in group B contain slightly more proteins than the foods in group $\mathrm{C}$, the major difference between the foods in the two groups lies in their calorie content. This comparison measures the mothe preference for calories in a child's diet. Only 33 percent of the respondents chose the high calorie foods in group B, the cereals. Sixty-seven percent of the mothers preferred the nutritionally poorer foods in group $\mathrm{C}$, green bananas, Irish potatoes, cabbage and orange. Thus, when protein content is more or less constant, Kikuyu mothers seem to prefer low calorie foods.

$A-C$ comparisons Foods in group $\mathrm{A}$ are high in calories and proteins; foods in group $\mathrm{C}$ are low in both. We have already found that group $\mathrm{A}$, the legumes and animal products, and group $\mathrm{C}$, the roots, vegetables and fruits, are preferred over group B, the cereals; group A more than group C. 
Consequently one would expect group $\mathrm{A}$ to be preferred to group $\mathrm{C}$, although to a lesser extent than to group B. This expectation is confirmed, 65 percent of the respondents chose group $\mathrm{A}$ foods over group $\mathrm{C}$ foods.

These findings show that Kikuyu women have a strong preference for high protein foods on the one

? hand and for low calorie foods on the other hand. Although we do not wish to suggest that these women consciously choose in this way, these - nevertheless are their preferences and this is important for the nutrition programmes in the area.

\section{CONCLUSION \\ .)}

Nutrition programmes in developing countries, whether practically or research oriented, require a substratum of information from which to proceed. Such information should, of course, include knowledge and vernacular names of local foods. Other aspects are often left unexplored or taken for granted; these include the way in which people classify their foods. In the present case, although the Kikuyu use only a few generic food terms, their classification system appears to follow the customary nutritional division of the Western World. Although, the method used here to study this question is limited, it is a simple and quick method that can easily explore food cognition in different cultures. This is important when it is necessary to confirm whether food groups introduced in nutrition education, for example bodybuilding foods, have anything in common with local classification. Foods with marginal positions, "hat is foods that do not clearly belong to a particu-

-... at group, can be identified. Among the Kikuyu, examples are whole maize, rice and green bananas.

The present studies were primarily concerned with the measurement of maternal food preferences. It was shown that the method of paired comparisons is well suited to this, particularly among rural women who usually have a limited education. This kind of questionnaire has great advantages, particularly in situations where written interviews cannot be used. Misunderstandings are reduced because only one or a few basic questions are used throughout the interviews. The method of paired comparisons also has the advantage that respondents have to choose between only two alternatives. Uneducated respondents prefer this to other response methods that either have more alternatives, rely on ratings, or use openended questions. The interviews also tend to take little time.

The high reliability coefficients indicate that differences in food preferences can be studied using only small groups of respondents. Food preferences are also remarkably stable for different parts of Kikuyu country. Although Kikuyu women are willing to choose between all kinds of foods, it should not be assumed that this is true with other groups. In Uganda, for example, the Baganda draw a strict distinction between staple food and relish, and mothers were not willing to choose between foods from these different groups. There, comparisons had to be drawn between meals, not single foods (Hoorweg and McDowell, 1979).

Finally, it is possible to measure protein preferences and calorie preferences independent of each other. Kikuyu mothers prefer high protein foods (which also have high caloric values) such as beans, peas, meat and eggs for their children. At the same time, Kikuyu mothers next prefer foods that are low in calories and low in proteins such as green bananas, Irish potatoes and cabbage. It is very likely that they will fall back on these foods when the high protein-high calorie foods are not available. This suggests that nutrition education among these women should also emphasize foods of high caloric value such as maize flour, millet flour and rice while foods with a high protein content have mainly been stressed until now.

\section{REFERENCES}

Anderson, T. F. (1937). Kikuyu diet. East African Medical Journal, 14, 120-131.

Benson, T. G. (1964). Kikuyu-English Dictionary. Oxford: Clarendon Press.

Benson, T. G. and A. R. Barlow (1975). English-Kikuyu Dictionary. Oxford: Clarendon Press.

Bertin, J., J-J. Hémardınquer, M. Keul and W. G. K. Randles (1971). Atlas of Food Crops. The Hague: Mouton.

Blankhart, D. (1974). Regional Names of Foods in Kenya. Nairobi: Medical Research Centre, mimeo.

Bohdal, M., N. E. Gibbs and W. K. Simmons. Nutrition Survey and Campaign against Malnutrition in Kenya, 1964-68. Nairobi: Ministry of Health, no date.

C.B.S. (1977). The rural Kenyan nutrition survey; FebruaryMarch, 1977. Social Perspectives, 2, (4).

Gopalan, C. (1968). Kwashiorkor and marasmus: evolution and distinguishing features. In McCance, $R$. and Widdowson, E. (eds.) (1968). Calorie Deficiencies and Protein Defictencres. London: Churchill, p. 49.

Hoorweg, J. and I. McDowell (1979). Evaluation of Nutrition 
Education in Africa: Community Research in Uganda, 1971-72. The Hague: Mouton.

Hoorweg, J. and R. Niemeyer (1978a). Classification of Foods among the Kikuyu. Leiden: Africa Studycentre, NIRP report 7 , mimeo.

Hoorweg, J. and R. Niemeyer (1978b). Preferences of Kikuyu Mothers for Children's Foods. Leiden: Africa Studycentre, NIRP report 8 , mimeo.

Kendall, M. G. (1970). Rank Correlation Methods. London: Griffin, 3rd edition.

Leakey, L. S. (1977). The Southern Kikuyu before 1903. (3 vols.) London: Academic Press.

McLaren, D. S. (1974). The great protein fiasco. Lancet (2), 93-96.

Middleton, J. and G. Kershaw (1965). The Central Tribes of the North-Eastern Bantu (revised ed.). London: International African Institute.

NIRP (1976). Nutrition Intervention and Environment, Research Proposal. Leiden: Africa Studycentre, mimeo.

NIRP (1977). A Short Dictionary of Kikuyu Names of Foods,
Meals and Drinks. Report no. 3. Leiden: Africa Studycentre, mimeo.

NIRP (1978). Revised Research Plan. Report no. 5. Leiden: Africa Studycentre, mimeo.

Orr, J. B. and J. L. Gilks (1931). Studies of Nutrition: The Physique and Health of Two African Tribes. Medical Research Council, special report 155. London: HMSO.

Platt, B. S. (1962). Tables of Representative Values of Foods commonly used in Tropical Countries (revised ed.). Medical Research Council, special report 302. London: HMSO.

Procter, R. A. W. (1926). The Kikuyu market and Kikuyu diet Kenya Medical Journal, 3, 15-22.

Romney, A. K., R. N. Shepard and S. B. Nerlove (eds.) (1972). Multidimensional Scaling ( 2 vols.). New York: Seminar Press.

Routledge, W. S. and K. Routledge (1910). With a Prehistoric People: The Akikuyu of British East Africa. London: Cass (reprint 1968).

Torgerson, W. (1958). Theory and Methods of Scaling. New York: Wiley. 